\title{
An Overview of Rice Cultivation in Spain and the Management of Herbicide-Resistant Weeds
}

\author{
Diego Gómez de Barreda ${ }^{1}$, Gabriel Pardo ${ }^{2}$, José María Osca ${ }^{1}$ (), Mar Catala-Forner ${ }^{3}{ }^{\circledR}$, Silvia Consola ${ }^{4}$, \\ Irache Garnica ${ }^{5}$, Nuria López-Martínez ${ }^{6}$, José Antonio Palmerín ${ }^{7}$ and Maria Dolores Osuna ${ }^{8, *}$ (i)
}

Citation: Gómez de Barreda, D.; Pardo, G.; Osca, J.M.; Catala-Forner, M.; Consola, S.; Garnica, I.; López-Martínez, N.; Palmerín, J.A.; Osuna, M.D. An Overview of Rice Cultivation in Spain and the Management of Herbicide-Resistant Weeds. Agronomy 2021, 11, 1095. https://doi.org/ 10.3390/agronomy11061095

Academic Editors: Francesco Vidotto and Silvia Fogliatto

Received: 6 May 2021

Accepted: 26 May 2021

Published: 28 May 2021

Publisher's Note: MDPI stays neutral with regard to jurisdictional claims in published maps and institutional affiliations.

Copyright: (c) 2021 by the authors. Licensee MDPI, Basel, Switzerland. This article is an open access article distributed under the terms and conditions of the Creative Commons Attribution (CC BY) license (https:/ / creativecommons.org/licenses/by/ $4.0 /)$.
1 Plant Protection Department, Universitat Politècnica de València, Camino de Vera s/n, 46022 Valencia, Spain; diegode@btc.upv.es (D.G.d.B.); josca@upv.es (J.M.O.)

2 Plant Protection Department, Agrifood Research and Technology Centre of Aragon (CITA), AgriFood Institute of Aragon-IA2 (CITA-University of Zaragoza), Avenida Montañana 930, 50059 Zaragoza, Spain; gpardos@aragon.es

3 Institute of Agrifood Research and Technology (IRTA), Estació Experimental de l'Ebre, Ctra. de Balada, km 1, 43870 Amposta, Spain; mar.catala@irta.cat

4 Plant Health Service (DARP), Generalitat de Catalunya, Ctra. de Valencia, 108, 43520 Roquetes, Spain; silvia.consola@gencat.cat

5 Institute for Agrifood Technology and Infrastructures of Navarra (INTIA), Edificio Peritos, Avda. Serapio Huici 22, Navarre, 31610 Villava, Spain; igarnica@intiasa.es

6 Agronomy Department, High Technical School of Agronomic Engineering (ETSIA), University of Sevilla, Ctra. de Utrera, 41013 Sevilla, Spain; nlopez@us.es

7 Plant Health Service, Government of Extremadura, Ctra. de Miajadas, km 2,5, Don Benito, 06400 Badajoz, Spain; joseantonio.palmerinr@juntaex.es

8 Plant Protection Department, Extremadura Scientific and Technological Research Center (CICYTEX), Ctra. de AV, km 372, Badajoz, 06187 Guadajira, Spain

* Correspondence: mariadolores.osuna@juntaex.es

Abstract: Spain is the second highest rice-producing country in the European Union, with approximately 105,000 ha used to grow this crop. The major rice-producing regions in Spain are Andalusia, Extremadura, Catalonia, and Valencia, followed by Aragon and Navarre. The main soil texture throughout Spanish rice areas is silty clay loam, with alkaline soils ( $\mathrm{pH}>7.5$ )-except in the Extremadura area $(\mathrm{pH}=5.5-6)$ - and a low organic matter content. Water quality in terms of salinity is acceptable, although in some coastal rice areas salinity issues occasionally appear to be a determining factor for high yield achievement. According to a survey carried out on farmers and technicians, the most problematic weeds found in rice crops today in Spain are Echinochloa spp., Leptochloa spp., and Cyperus difformis. Most of the currently authorized herbicides can be classified according to two modes of action: ALS-inhibiting and ACCase-inhibiting. Repeated field applications of herbicides with the same mode of action have resulted in the selection of herbicide-resistant weeds. At present, resistance has been confirmed in different regions of Spain to ALS inhibitors in Echinochloa spp., Leptochloa spp., and Cyperus difformis, and to ACCase inhibitors in Echinochloa spp. and Leptochloa spp. The mechanism of resistance in these species is a mutation in the target site of these herbicides. Several mutations have been found in the ALS gene, both in Echinochloa spp. and Cyperus difformis, distributed in the different rice-growing regions considered in this work. ACCase gene mutations have been mainly found in Leptochloa spp. individuals from Extremadura and Valencia. These different mutations have resulted in different patterns of cross-resistance to ALS- and ACCase-inhibiting herbicides. It is likely that the repeated use of these two modes of action in rice will result in the evolution of more resistant weed populations. The possible availability of new herbicides with alternative modes of action in a short space of time seems very limited, suggesting the need for a more appropriate use of the available alternative strategies (crop rotation, dry sowing, manual weeding, etc.). This work presents a review of the main characteristics of rice cultivation in Spain, emphasizing the current problems in this crop and the management of herbicide-resistant weeds. 
Keywords: barnyard grass; crop protection; herbicide; target-site resistance; rice; weed management; weed science

\section{Introduction}

Rice is one of the most important global food crops, and a primary source of calories for more than half of the world's population [1]. Molina et al. [2] dated the origin of its domestication to $8200-13,500$ years ago in the Yangtze Valley in China. However, it was not cultivated in Europe until the 12th century, when Arabs brought the crop to the Iberian Peninsula, from where rice was exported to other European countries throughout the Mediterranean Basin [3].

\subsection{Main Rice-Growing Areas in Spain}

Over the centuries, this crop has passed through different periods of development and crises in Spain for various reasons, including the negative association of rice with people's health, wars, and decreases in rural populations and the labor force. At first, rice was cultivated in areas with high water availability, such as marshy areas and river deltas in the Andalusian, Catalonian, and Valencian regions. From the end of the 19th century and the beginning of the 20th, the traditional rice-growing regions saw an increase in the amount of land dedicated to this crop, and its cultivation began to spread to other nontraditional areas, such as Aragon, Extremadura, and Navarre. Today, this crop occupies around 105,000 ha. Rice in Spain is mainly cultivated in 6 of its 17 administrative regions (Figure 1), from latitude 37 in Marismas del Guadalquivir (Andalusia region) to latitude 42 in Navarre and Aragon. Table 1 shows how the main rice cultivation area in Spain is located in the two southernmost areas (Marismas del Guadalquivir and Extremadura), followed by the two Mediterranean coastal rice areas (Delta del Ebro and Valencia), with the northern rice areas (Aragon and Navarre) lagging behind.

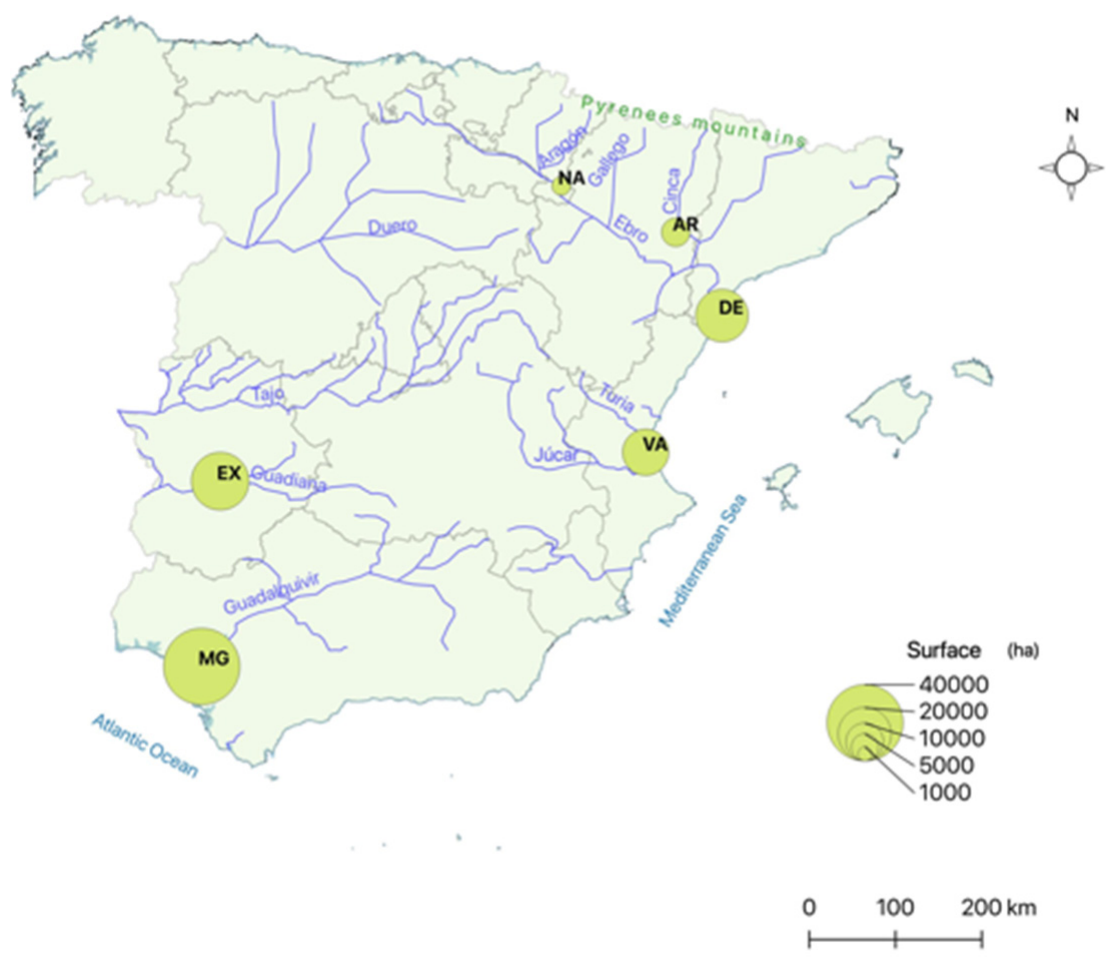

Figure 1. Main rice areas in Spain. AR (Aragon); DE (Delta del Ebro); MG (Marismas del Guadalquivir); NA (Navarre); VA (Valencia); EX (Extremadura). 
Table 1. Surface area and yield in the major Spanish rice areas. Data from [4].

\begin{tabular}{ccccccc}
\hline & \multicolumn{3}{c}{ Surface (ha) } & \multicolumn{2}{c}{ Yield (kg ha $^{-\mathbf{1})}$} \\
\cline { 2 - 7 } & Total & Long Grain & Medium-Short Grain & Average Field & Long Grain & Medium-Short Grain \\
\hline Aragon & 5077 & - & 5077 & 2 & - & 5705 \\
Delta del Ebro & 19,847 & 1489 & 18,358 & 2 & 7735 & 7018 \\
Extremadura & 21,355 & 14,755 & 6600 & 4 & 7180 & 8063 \\
Marismas del Guadalquivir & 39,635 & 26,853 & 12,782 & 27 & - & 5621 \\
Navarre & 2004 & - & 2004 & $<1$ & - & 8496 \\
Valencia & 14,806 & - & 14,806 &
\end{tabular}

Rice cultivation in traditional areas (Delta del Ebro, Marismas del Guadalquivir, and Valencia) is carried out following a monoculture system. Although rice is one of the most salt-sensitive crops, cultivation using freshwater flood irrigation allows the lowering of salinity levels, and thus, its cultivation in highly salinized fields. Crop rotation in these coastal rice regions has failed due to the high and rapid salinization of rice fields as soon as the irrigation water is withdrawn, with salinity strongly conditioning the crop alternatives that can be grown [5]. While variation through crop rotation is the main way to overcome the negative aspects of intensive monoculture cropping, including the effects on soil fertility, and pathogen, pest, and weed control [6], this integrated management approach fails in coastal rice-growing areas with salinity issues. In the more recently developed rice areas, all located inland (Aragon, Extremadura, and Navarre), rice is sometimes rotated with other crops: in Aragon with annual ryegrass (Lolium multiflorum Lam.), barley (Hordeum vulgare L.), tall fescue (Schedonorus arundinaceus (Schreb.) Dumort.), or even with fallow land; in Navarre, some $20 \%$ of the rice area is mainly rotated with winter cereals, fallow land, tomatoes (Solanum lycopersicum L.), and broccoli (Brassica oleracea var. italica Plenck); and in Extremadura with corn (Zea mays L.) and tomatoes. Some of these rotations are carried out in other rice-growing regions in the world. In temperate regions, rice is mostly rotated with wheat (Triticum sp.) or peas (Pisum sativum L.), while in warm regions possible candidates for rotations include forage crops, maize, or sunflowers [5]. In Italy, soybeans (Glycine $\max$ L.) and maize have recently proven to be successful rotation crops in rice fields [7].

\subsection{Main Commercial Rice Varieties}

Rice is divided into three types based on seed size: long-grain, medium-grain, and short-grain. Long-grain rice is the most versatile and popular variety worldwide [8,9]. However, the preferred type in Spain is short-grain rice, which has a particularly long tradition in the Mediterranean coastal regions [10]. Long-grain varieties (Oryza sativa var. indica) are mainly cultivated in rice areas located in southern Spain (Extremadura and Marismas del Guadalquivir), while in the other four areas located in northeastern Spain, short-medium-grain (Oryza sativa var. japonica) rice is cultivated. The main commercial varieties are shown in Table 2. It can be observed how, in the areas with the lowest rice crop surface area (Aragon and Navarre), one particular variety ("Guadiamar") is dominant. This is also the case in the Marismas del Guadalquivir rice area, where the "Puntal" long-grain variety is by some distance the most cultivated. In the Delta del Ebro and Valencia rice areas, the "JSendra" variety, recently released by a Valencian rice research institute, has been gaining in popularity due to its improved agronomic and culinary characteristics. Of all of the rice varieties cultivated in Spain, a special mention should be reserved for the new Clearfield ${ }^{\circledR}$ varieties ("Sirio", "Furia", "CLX755", and "Ecco 51"), which carry imidazolinone-resistant traits that provide an efficient option for weed control. However, these varieties are not evenly spread throughout Spain, with the main region where they are grown being Extremadura, where they occupy almost $50 \%$ of the rice-growing area. Here, Clearfield ${ }^{\circledR}$ varieties are not only used to get rid of weedy rice, but also for Leptochloa spp. control [11]. 
Table 2. The main rice varieties cultivated in each of the six Spanish rice areas, including in brackets their cultivated \% among the rest of the varieties in the same area.

\begin{tabular}{cccccc}
\hline Aragon & Delta del Ebro & $\begin{array}{c}\text { Marismas del } \\
\text { Guadalquivir }\end{array}$ & Navarre & Valencia & Extremadura \\
\hline Guadiamar (75) & JSendra (35) & Puntal (73) & Guadiamar (91) & JSendra (44) & Sirio (25) \\
Nuovo Maratelli (8) & Argila (16) & JSendra (13) & Nuovo Maratelli (4) & Gleva (21) & Gladio (22) \\
Bomba (6) & Bomba (16) & Guadiagran (2) & Lido (2) & Bomba (12) & CLX745 (14) \\
Furia (5) & Soto (5) & Guadiamar (2) & Onice (2) & Fonsa (10) & Thaiperla (13) \\
Sirio (1) & Sirio (4) & Sirio (2) & & Argila (5) & Ecco 51 (9) \\
& Montsianell (4) & Fonsa (2) & & Sirio (3) & Bomba (6) \\
& Furia (3) & & Soto (2) & \\
\hline
\end{tabular}

\subsection{Soil Characteristics and Temperature/Water Requirements}

The areas where Spanish rice fields are located have different soil types with different hydrological characteristics. As shown in Table 3, the main soil texture throughout Spanish rice areas is silty clay loam, with alkaline soils $(\mathrm{pH}>7.5)$ - except in the Extremadura area ( $\mathrm{pH}=5.5-6)$-and a low organic matter content. Both of these soil characteristics- $\mathrm{pH}$, and organic matter content-are important determining factors in rice production, as they are strongly correlated with soil micronutrient availability and uptake by rice plants [12].

Table 3. The main soil characteristics of the major Spanish rice areas.

\begin{tabular}{cccc}
\hline & Texture & $\mathbf{p H}$ & Organic Matter (\%) \\
\hline Aragon & Silty clay loam & 7.7 & 2.0 \\
Delta del Ebro & Silty clay loam & 8.0 & 3.5 \\
Extremadura & Sandy loam-clay loam & $5.5-6.0$ & $<2.0$ \\
Marismas del Guadalquivir & Clay-silty clay & $7.9-8.3$ & $1.5-3.2$ \\
Navarre & Silty clay loam & 8.0 & $1.5-2.5$ \\
Valencia & Clay loam-silty clay & 7.9 & 3.2 \\
\hline
\end{tabular}

Rice requires a lot of water throughout its cropping cycle-around 10,000-14,000 $\mathrm{m}^{3} \mathrm{ha}^{-1}$ (1000-1400 mm) - but rainfall during the rice cycle in Spain (May-October) is scarce (Figure 2), around 130-250 mm. Just 4-58 $\mathrm{mm}$ of rain falls during the July-August periodpossibly the most water-demanding period of the rice cycle. Therefore, irrigation is a necessity, and is mainly conducted through flood irrigation systems, with just a few areas in Extremadura using intermittent sprinkler irrigation. This high dependency on irrigation water is one of the main differences between rice production systems in Spain and the major rice production areas of Asia. Auffhammer et al. [13] reported around $1200 \mathrm{~mm}$ of rainfall from June to September in the Kharif rice-growing region of India, while in the same period of the year in the Spanish rice-growing areas the average rainfall is $92 \mathrm{~mm}$.

Figure 1 also shows the water sources for the different Spanish rice regions. In the northern rice areas (Aragon and Navarre), the main source is from rivers flowing from the Pyrenees mountains to the long Ebro River. Water quality is high in terms of salinity, and the field water depth ranges from 10 to $20 \mathrm{~cm}$. Once the Ebro River flows into the sea, it forms a large delta (Delta del Ebro), where rice is cultivated with a 5-10 $\mathrm{cm}$ water depth and a water salinity with an electrical conductivity (EC) of around $1.5 \mathrm{dS} \mathrm{m}^{-1}$. In the Marismas del Guadalquivir rice area, the source of the irrigation water is the Guadalquivir river, with a field water depth of $10-20 \mathrm{~cm}$ and a low water quality in terms of salinity $\left(E C=2.3 \mathrm{dS} \mathrm{m}^{-1}\right)$. There are diverse water sources in the Valencia rice area, as part of the rice fields is flooded from a coastal freshwater lake $\left(E C=2.1 \mathrm{dS} \mathrm{m}^{-1}\right)$, and the rest from a complex network of water canals diverted from the Turia and Júcar rivers $\left(E C=1.2 \mathrm{dS} \mathrm{m}^{-1}\right)$ flowing north and south, respectively, of the rice area. Finally, in the Extremadura rice area, the water comes from the Guadiana River, with an average flood depth of $15-20 \mathrm{~cm}$ and good salinity quality $\left(\mathrm{EC}=0.25-0.3 \mathrm{dS} \mathrm{m}^{-1}\right)$. 


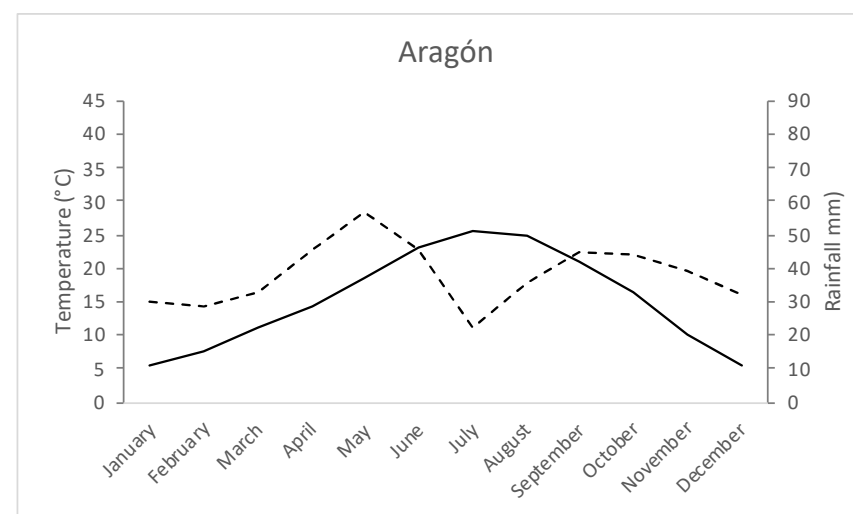

Marismas del Guadalquivir

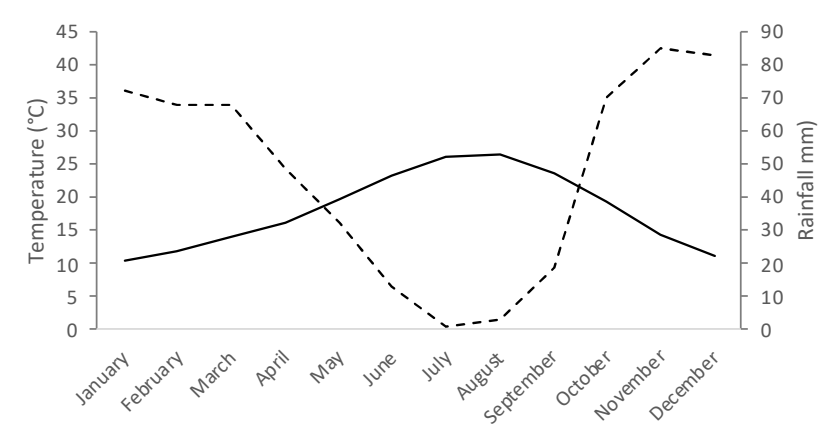

Valencia

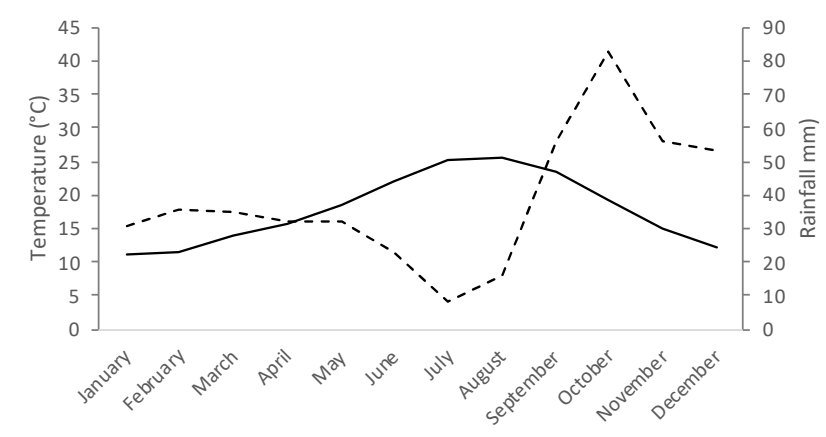

\section{Delta del Ebro}

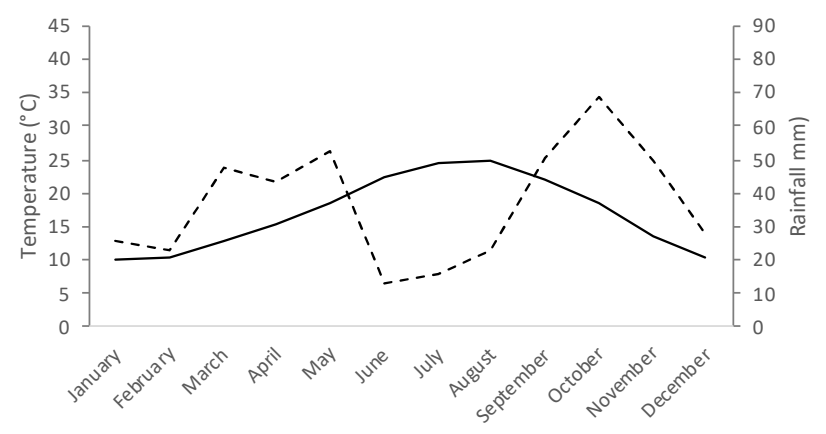

Navarra

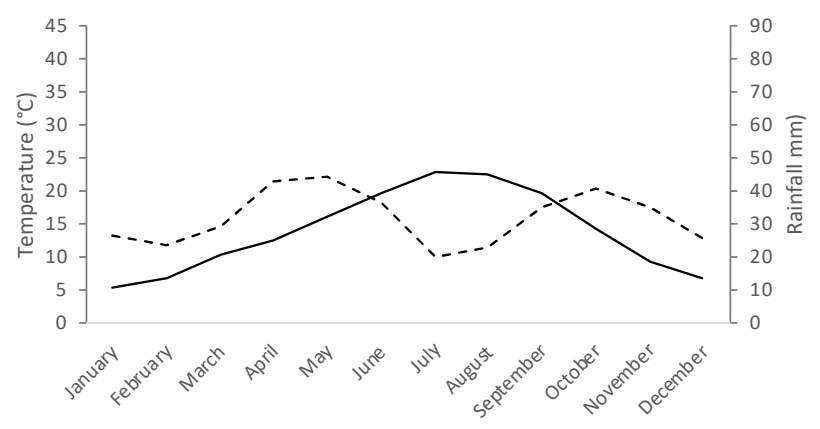

Extremadura

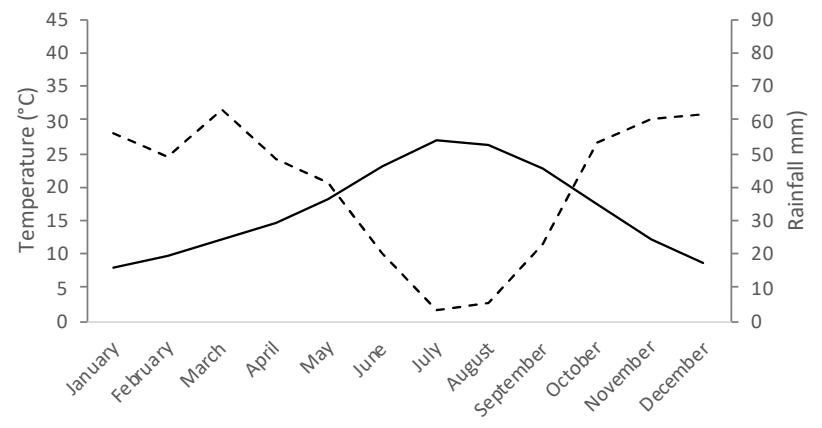

Figure 2. Ombrothermic diagrams of the six Spanish main rice areas. Solid line: mean temperature; dashed line: rainfall. Data are from a recent 20-30-year series for each rice area.

As can be seen in Figure 1, some of the Spanish rice areas are located in the north of the country (Aragon and Navarre), where a short warm period presents an obstacle to achieving high yields. In these two areas, rice yields are around $5600 \mathrm{~kg} \mathrm{ha}^{-1}$, whereas the corresponding values in the Marismas del Guadalquivir and Valencia areas are around $8500 \mathrm{~kg} \mathrm{ha}^{-1}$. However, this large difference is not only due to air temperature, as the number of growing degree days for Aragon in the May-September period is 1940, more than in the Delta del Ebro area (1906 growing degree days), with almost the same latitude but a rice yield of around $7000 \mathrm{~kg} \mathrm{ha}^{-1}$. There is an additional important factor in these northern rice areas that affects rice yields: a low water temperature. In Aragon and Navarre, the rice fields are fed from cold rivers directly flowing from the Pyrenees. Shimono et al. [14] reported that an important reason for rice yield reduction is low water temperature, as it directly decreases the photosynthetic rate.

\section{Weed Control in Rice in Spain}

Rice in Spain is mostly cultivated under flood irrigation conditions from May to October. These anaerobic soil conditions constitute the first barrier against weed infesta- 
tion, considered the most harmful of the different types of organism that can affect rice production [15]. However, several weed species have adapted to these conditions, exerting a considerable pressure on the rice crops. The most competitive and difficult to control rice weed species in Spain (Table 4) are Echinochloa spp., along with some Cyperaceae, present in most European rice-growing regions [16-19]. In other parts of the world, for example in Arkansas and California in the USA [20,21], and in Asian countries such as Japan [22] and China [23], the most harmful rice weeds are similar to those occurring at in Europe: Echinochloa spp., and species of the Cyperaceae family [16].

Table 4. Infestation level * of rice weeds in the six main Spanish rice areas, based on an evaluation by a panel of experts classifying weed species into five categories.

\begin{tabular}{|c|c|c|c|c|c|c|}
\hline Weed Species & Aragon & Delta del Ebro & Marismas del Guadalquivir & Navarre & Valencia & Extremadura \\
\hline Echinochloa sp. & 5 & 4 & 5 & 4 & 5 & 5 \\
\hline Oryza sativa & 3 & 2 & 1 & 2 & 2 & 1 \\
\hline Leptochloa sp. & 2 & 2 & 2 & 3 & 2 & 5 \\
\hline Leersia oryzoides & 0 & 2 & 0 & 0 & 0 & 0 \\
\hline Cyperaceae & 4 & 4 & 5 & 5 & 3 & 4 \\
\hline Heteranthera sp. & 2 & 3 & 1 & 5 & 1 & 2 \\
\hline Alisma sp. & 0 & 2 & 1 & 2 & 0 & 3 \\
\hline Ammania sp. & 0 & 0 & 1 & 0 & 0 & 1 \\
\hline Algae & 2 & 2 & 1 & 2 & 1 & 2 \\
\hline
\end{tabular}

* $0-5$ scale, where a 5 means maximum level of infestation, and a 0 means no presence of a particular weed.

Weed control in the Spanish rice areas underwent a dramatic change in the late 1960s, when farmers changed the propagation method from transplanting to direct seeding due to herbicide availability and a scarce labor force. Generally, herbicides are easy to use, as well as being more effective and less expensive than manual labor [24]. Until then, rice transplanting plus weeding by hand had constituted the main weed control strategy, but herbicides became essential when direct seeding was adopted. The first recommended selective herbicides for weed control in rice in Spain were synthetic auxin types (2,4-D; 2,4,5TP; MCPA; MCPP), dichlobenil, molinate, and propanil [25]. In the 1980s and 1990s, other herbicides were introduced for rice crops: bensulfuron-methyl, bentazone, clomazone, mefenacet, oxadiazon, pendimethalin, quinclorac, thiobencarb, and triclopyr. Then, in the last two decades, other active ingredients became available: azimsulfuron, bispyribac-Na, cyhalofop-butyl, halosulfuron, imazamox, profoxydim, and penoxsulam, mainly for the control of Echinochloa spp. In 2020 there were two exceptional authorizations: propanil-a herbicide that had been used in Spain for many years-and a new herbicide molecule called florpyrauxifen-benzyl, mainly focused on the control of Alisma plantago-aquatica, Cyperus spp., Ammania spp., and Echinochloa spp.

Rice herbicides have therefore been applied in Spain for at least 50 years, with some of them belonging to herbicide families known for their high potential to produce herbicideresistant weeds, including acetyl-CoA carboxylase (ACCase) inhibitors and acetolactate synthase (ALS) inhibitors. The authorized herbicides for rice in Spain, and their specific uses for the most problematic weeds in Spain, are specified and listed in Table 5.

Different chemical strategies against weeds, mainly centered on the control of Echinochloa spp., Leptochloa spp., Cyperus spp., and Oryza sativa (red rice) weed species, are being conducted in the Spanish rice areas. Apart from the herbicides and the mixtures shown in Table 5, alternative mixtures are being used in different rice-growing areas. By way of example, a profoxydim-cyhalofop-butyl mixture is being used in Extremadura, Valencia, and Aragon, mainly for the control of Echinochloa spp., and a cyhalofop-butyl-clomazone mixture in Navarre. A bentazone-MCPA mixture is also extensively used in Extremadura, mainly for the control of Cyperus difformis. 
Table 5. Herbicides authorized for rice cultivation in Spain in the 2020 season [26].

\begin{tabular}{|c|c|c|c|}
\hline Active Ingredient & Mode of Action & Main Target Species & Comments \\
\hline \multicolumn{4}{|c|}{ Pre-Sowing } \\
\hline Cycloxydim $\left(^{*}\right)$ & A/1 (ACCase inhibitors) & OS & \\
\hline Propaquizafop & A/1 (ACCase inhibitors) & $\mathrm{OS}, \mathrm{ECH}$ & \\
\hline \multicolumn{4}{|c|}{ Pre-Emergence } \\
\hline Clomazone $(* *)$ & F4/13 (DOXP inhibitors) & $\mathrm{ECH}$ & Dry-seeded rice \\
\hline Pendimethalin & K1/3 (Microtubule inhibitors) & NS & Dry-seeded rice \\
\hline Pendimethalin + clomazone & $\mathrm{F} 4 / 13+\mathrm{K} 1 / 3$ & MON, DIC & Dry-seeded rice \\
\hline \multicolumn{4}{|c|}{ Post-Emergence } \\
\hline Azimsulfuron & B/2 (ALS inhibitors) & $\mathrm{AL}, \mathrm{AM}, \mathrm{CYP}, \mathrm{SC}, \mathrm{ECH}, \mathrm{HE}$ & \\
\hline Bensulfuron-methyl & B/2 (ALS inhibitors) & $\mathrm{AL}, \mathrm{CYP}$ & \\
\hline Bentazone & C3/6 (PSII inhibitors) & CYP, DIC & \\
\hline Bispyribac-sodium & B/2 (ALS inhibitors) & $\mathrm{CYP}, \mathrm{ECH}$ & \\
\hline Cyhalofop-butyl & A/1 (ACCase inhibitors) & $\mathrm{ECH}, \mathrm{LP}$ & \\
\hline Halosulfuron-methyl & B/2 (ALS inhibitors) & CYP, DIC & \\
\hline Imazamox & B/2 (ALS inhibitors) & NS & Clearfield ${ }^{\circledR}$ varieties \\
\hline MCPA & O/4 (synthetic auxins) & DIC & \\
\hline Penoxsulam & B/2 (ALS inhibitors) & $\mathrm{ECH}, \mathrm{AL}, \mathrm{AM}, \mathrm{CP}$ & \\
\hline $\begin{array}{l}\text { Penoxsulam + } \\
\text { cyhalofop-butyl }\end{array}$ & $\mathrm{B} / 2+\mathrm{A} / 1$ & $\mathrm{ECH}, \mathrm{LP}$ & \\
\hline Penoxsulam + triclopyr & $\mathrm{B} / 2+\mathrm{O} / 4$ & MON, DIC & \\
\hline Profoxydim & A/1 (ACCase inhibitors) & ECH, LP & \\
\hline
\end{tabular}

AL: Alisma plantago-aquatica; AM: Ammania sp.; CYP: Cyperus difformis; ECH: Echinochloa spp.; HE: Heteranthera spp.; OS: Oryza sativa (red rice); MON: monocots; DIC: dicots; NS: non-specified; $\left(^{*}\right)$ : authorized in post-emergence in Provisia ${ }^{\circledR}$ varieties (target species: ECH, OS, and MON); $\left({ }^{* *}\right)$ : authorized in pre-sowing, pre-emergence (dry-seeded rice), and early-post-emergence (flooded rice).

\section{Herbicide Resistance}

Several cases of herbicide-resistant weeds have already been detected in the Spanish rice areas in recent years [27-29]. Worldwide, the continuous use of herbicides has led to the evolution of herbicide-resistant weeds [24]. Importantly, 164 cases of rice weeds resistant to herbicides have been reported, including 69 cases involving Echinochloa spp. [30]. As a result of this resistance, as well as a significant decrease in the number of newly released herbicides and an increasingly strict regulation of herbicide use, especially in Europe, more effective tools are required to control weed populations. Integrated weed management, which aims to minimize the number of treatments while maximizing their efficacy, is thus a major guiding concept. From this perspective, it is of primary importance to unravel the genetic bases of herbicide resistance in weeds, and to understand how resistance genes evolve and spread among and within weed populations.

Understanding the mechanism(s) of herbicide resistance is a critical aspect in predicting the evolutionary trajectory of herbicide resistance [31]. Mechanisms of herbicide resistance in weeds can be broadly classified into target-site resistance (TSR) and/or nontarget-site resistance (NTSR) [32]. The TSR mechanisms mostly involve mutation(s) in the target site of action of an herbicide, resulting in an insensitive or less sensitive target protein of the herbicide [32].

A study was carried out from 2015 to 2018 by researchers from the different Spanish rice-growing areas, in which samples of the most problematic weeds were taken from each area. Different fields were selected where growers had reported poor control of Echinochloa spp., Leptochloa spp., and/or Cyperus difformis by ALS- and/or ACCase-inhibiting herbicides applied during the previous growing season, thus suggesting the occurrence of resistant populations. Since the main mechanism involved in resistance to ALS-inhibiting and ACCase-inhibiting herbicides is due to mutations at the site of action, a total of 391 samples (248 Echinochloa spp., 95 Leptochloa spp., and 48 Cyperus difformis) distributed in the different areas were analyzed following the methodology described by Amaro 
(2019) [33]. Evolved resistance to ALS-inhibiting herbicides in weeds has been attributed to substitutions at each of the following eight different amino acid positions: Ala-122, Pro-197, Ala-205, Asp-376, Arg-377, Trp-574, Ser-653, and Gly-654. Codon changes at positions 1781, $1999,2027,2041,2078,2088$, and 2096 have been previously described as causing resistance to ACCase-inhibiting herbicides. The tests were performed using pooled samples, and so the mutation frequency within the population was not determined. The results are shown in Figure 3.
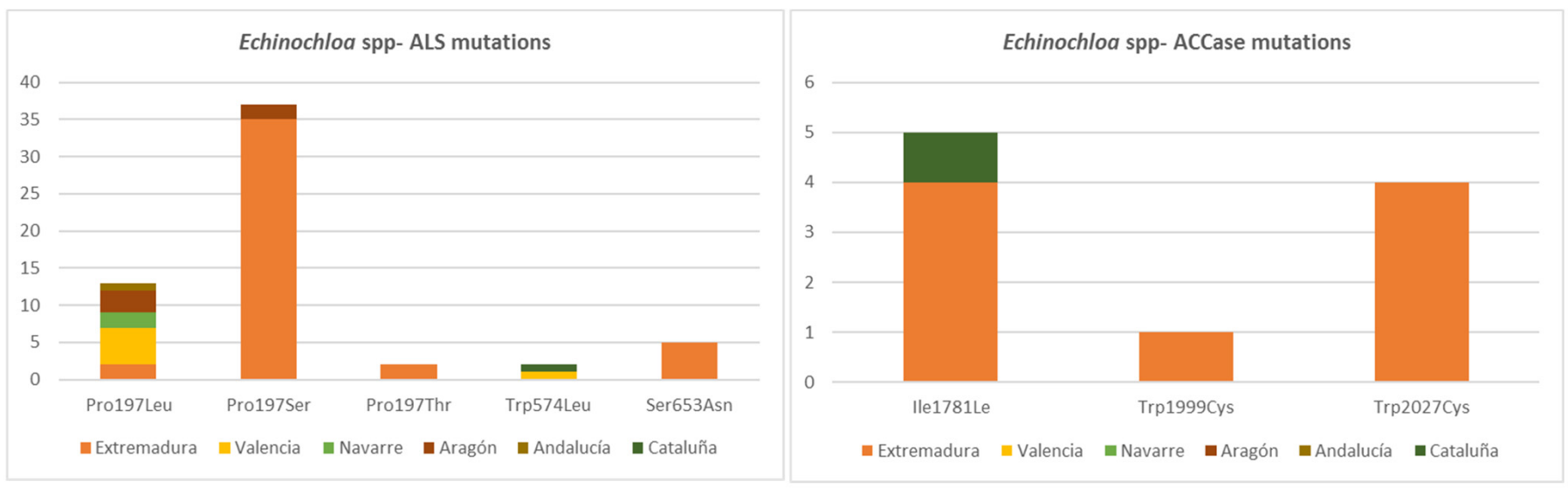

Leptochloa ssp.- ALS mutations

Leptochloa spp.-ACCase mutations
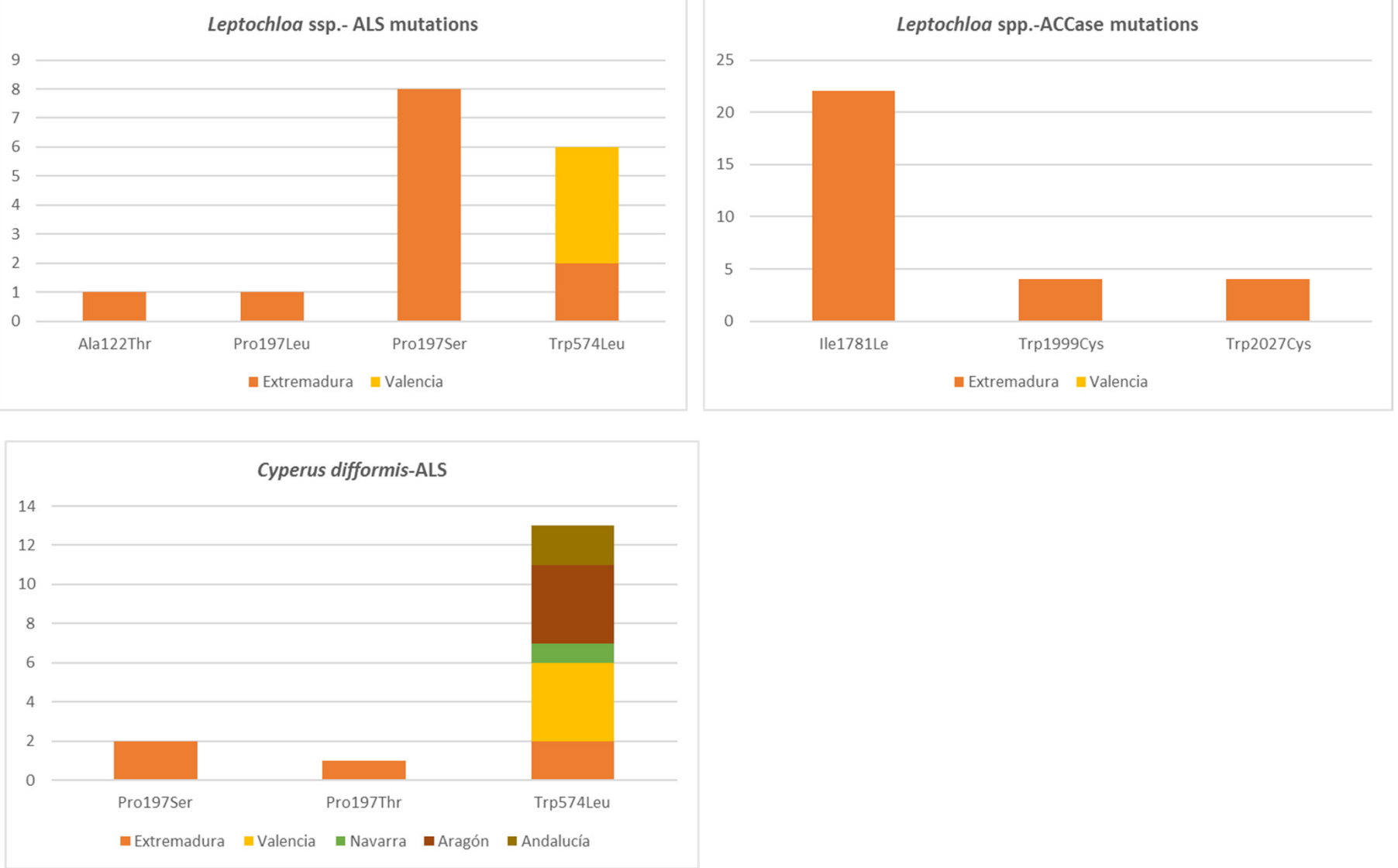

Figure 3. Different mutations in ALS and ACCase genes in individuals of Echinochloa spp., Leptochloa spp., and Cyperus difformis collected from different rice-growing areas of Spain.

In the case of Echinochloa spp., a greater number of mutations were found in the ALS gene. Pro197 mutations are the most frequently reported mutation type in weed species [34]. A Pro-197-Ser mutation has been previously described in Echinochloa spp., with confirmation that this mutation reduced the affinity for ALS inhibitors belonging to 
the triazolopyrimidine, sulfonylaminocarbonyltriazolinone, and sulfonylurea families [35]. Substitutions at Ala-122, Ser-653, and Trp-574 have been reported to confer resistance to ALS-inhibiting herbicides in several Echinochloa species [18,36,37]. As can be seen in Figure 3, fewer cases of mutations in the ACCase gene have been found in this species, and only in two rice-growing areas-in both cases in recent years (data not shown). This may be due to a greater use of ALS-inhibiting herbicides in the different zones, mainly penoxsulam and bispyribac-sodium.

In Leptochloa spp., target-site resistances have been found mainly in the Extremadura area, and a few isolated cases in the Valencia region. Most of the resistances are to ACCase inhibitors, with several amino acid changes in this gene. This weed was first described in Extremadura, and it is in this region that it continues to be one of the main problems. ACCase-inhibiting herbicides (especially profoxydim) have been used to control Leptochloa chinensis (L.) Ness, and displayed a major control effect in rice fields in China. However, the persistent and extensive use of profoxydim has resulted in the evolution of resistant populations. The three mutations found in these populations have been previously described in L. chinensis in rice [38]. This species also shows resistance to ALS inhibitors in Extremadura, with several cases found of multiple resistance to both families of herbicides (data not shown).

The ALS inhibitors used to control C. difformis in paddy fields in Spain are mainly penoxsulam and bensulfuron-methyl. However, the efficacy of these herbicides has decreased significantly in recent campaigns. In the samples of $C$. difformis analyzed for this study, the Trp-574-Leu change in the ALS gene was found in samples from different ricegrowing areas. This mutation has resulted in high resistance in C. difformis populations against all of the different ALS inhibitor families [39].

\section{Survey on Weed Control and Resistance Awareness in Spanish Rice Areas}

In order to determine the main management practices to control rice weeds, and farmer awareness of the evolution of herbicide resistance, a survey was conducted over a period of two years (from 2016 to 2017) in the main growing regions of Spain.

A total of 90 farmers and 108 technical advisors answered the survey, representing in almost equal proportions the 2 main types of cultivated rice: long- and medium-grain. The factors investigated were the most troublesome weeds, the herbicide mode of action used, cultural practices, and awareness of herbicide resistance. Categories within each factor were adjusted, and the frequency distribution of cases (\%) within each category of analyzed factors was calculated.

Firstly, the results of the survey showed that the most troublesome weeds are in line with those shown in Table 4, with Echinochloa spp. and Cyperaceae spp. the most important weeds, with values of 4.2 and 4.1 , respectively, on a $0-5$ subjective scale. The participants were also asked, using the same $0-5$ scale, about cultural practices for weed control performed in their rice fields. The most important ones were: water management (3.6), manual weeding (3.4), flooded-field ploughing before sowing (2.9), mechanical equipment cleaning (2.7), sowing dose increase (2.2), mechanical control (1.6), dry direct seeding (1.1), and crop rotation (0.86). However, these cultural weed control methods are not equally practiced in all Spanish rice-growing areas. Crop rotation was only important in the Navarre (3.1) and Extremadura (2.1) rice-growing areas, while it was almost nonexistent in the other areas. Dry direct seeding was only important in the Extremadura (2.6) area. Farmers and technical advisors were aware of the lack of herbicide efficacy, reporting possible weed resistance issues in the following order: Echinochloa spp. (2.9), Leptochloa spp. (2.8), Cyperaceae spp. (2.6), and Oryza sativa wild types (2.1).

Similar results have been found in other surveys that have been carried out recently in other rice-growing regions of the world [20,40]. Most farmers in the different regions rely on the repeated use of a narrow range of post-emergence herbicides. There is a need to diversify weed management options, especially for key grass weeds such as Echinochloa 
spp., Leptochloa spp., and Cyperaceae spp. The implementation of a sustainable integrated weed management strategy is required.

\section{Conclusions}

This study corroborates the presence of resistance to the most commonly used herbicides in rice cultivation in Spain (ALS and ACCase inhibitors), in many cases due to target-site resistance, although there are already confirmed cases in Echinochloa spp. due to herbicide metabolism (non-target-site resistance), mainly in the areas of Extremadura and Marismas del Guadalquivir [41]. In fact, from a global standpoint, there is considerable evidence that barnyard grass has the propensity to develop resistance to most of these herbicide groups [42]. It must not be forgotten that global climate change will induce higher temperatures and limited water availability, which will generally advantage C4 (e.g., barnyard grass) over C3 plants (e.g., rice) [43]. Moreover, one of the negative consequences of increasing temperature and $\mathrm{CO}_{2}$ levels could be the acceleration of the evolution of weeds' resistance to herbicides, and more specifically non-target-site resistance [44].

The possibility of the appearance of new herbicides with alternative modes of action in a short space of time seems very limited $[45,46]$. In order to avoid a disproportionate increase in resistance, which could endanger the viability of the crop, it is necessary to carry out a series of measures for the proper management of this important problem. This situation requires a more appropriate use of the available alternative strategies, including different strategies for each rice scenario (field scale), as the interaction between rice crop and weed management dictates the evolution of herbicide resistance [47].

Extremadura is currently the Spanish rice region with the most extensive problems in terms of the presence of weeds and confirmed cases of resistance. The use of alternatives when the problem is highly advanced can cause drastic changes in traditional farming systems. The example of Extremadura is noteworthy since, mainly due to the serious problems caused by weeds, the dry direct-seeded rice crop area was close to $80 \%$ of the total in the last rice season. In this system, the non-proliferation of aquatic weeds is attempted in the first stages of crop development, and allows the application of herbicides such as glyphosate and pendimethalin, which are successful in reducing rice weeds [48] and have a different mode of action compared to the main herbicides used for rice. In addition, in this cultivation system, alternative phytosanitary solutions are possible with different modes of action. However, we have also verified that these changes in cultivation methods should not be definitive since, in the long term, repetition in the same farming systems will ultimately cause similar problems. Concerted efforts at raising awareness of herbicide resistance, and the implementation of an effective integrated weed management program, are needed [49]. Moreover, diversification of crop and weed management practices, emphasizing nonchemical weed control tactics (e.g., stale seedbed management before rice sowing [50]) are important tools for the proactive management of herbicide-resistant weeds [51,52].

In summary, it is of great importance to know the situation of the resistance that we find in our rice fields, and a follow-up of its evolution will help us decide which phytosanitary, cultural, or cultivation methods should be adopted. Each rice-growing area in Spain has different characteristics, depending on the type of weather, soil, water availability, etc., and may require different strategies. However, measures have also been found that may be applicable to all or most of the rice-growing regions of Spain.

Author Contributions: Conceptualization, D.G.d.B. and M.D.O.; methodology, all authors.; investigation, all authors.; resources, all authors.; data curation, all authors.; writing - original draft preparation, D.G.d.B. and M.D.O.; writing—review and editing, D.G.d.B. and M.D.O.; visualization, all authors.; supervision, D.G.d.B. and M.D.O.; project administration, M.D.O.; funding acquisition, M.D.O. All authors have read and agreed to the published version of the manuscript.

Funding: This research was funded by the by the National Institute of Agricultural and Food Research and Technology (INIA, RTA2017-0098).

Institutional Review Board Statement: Not applicable. 
Informed Consent Statement: Not applicable.

Acknowledgments: The authors are grateful to Maria Carmelo García and Susana Hernández for providing data on the Aragon rice area, to Yolanda Romano and Raquel Gordo for their assistance in the laboratory and to the editors and the anonymous reviewers for their constructive comments and suggestions, allowing us to improve the final version of this article.

Conflicts of Interest: The authors declare no conflict of interest.

\section{References}

1. Dogara, A.; Jumare, A. Origin, distribution and heading date in cultivated rice. Int. J. Plant Biol. Res. 2014, $2,1008$.

2. Molina, J.; Sikara, M.; Garud, N.; Flowers, J.M.; Rubinstein, S.; Reynolds, A.; Huang, P.; Jackson, S.; Schaal, B.A.; Bustamante, C.D.; et al. Molecular evidence for a single evolutionary origin of domesticated rice. Proc. Natl. Acad. Sci. USA 2011, 108, 8351-8356. [CrossRef]

3. Ferrero, A.; Vidotto, F. History of rice in Europe. In Rice: Origin, Antiquity and History; Science Publishers: Enfield, NH, USA, 2010; pp. 341-372.

4. Spanish Ministry of Agriculture, Fisheries and Food. Anuario de Estadística; Spanish Ministry of Agriculture, Fisheries and Food: Madrid, Spain, 2019; p. 846.

5. Pardo, G.; Marí, A.I.; Aibar, J.; Cirujeda, A. Do Crop Rotations in Rice Reduce Weed and Echinochloa spp. Infestations? Recommendations for Integrated Weed Control. Agronomy 2021, 11, 454. [CrossRef]

6. Grzebisz, W.; Łukowiak, R.; Sassenrath, G.F. Virtual nitrogen as a tool for assessment of nitrogen management at the field scale: A crop rotation approach. Field Crop Res. 2018, 218, 182-194. [CrossRef]

7. Arcieri, M.; Ghinassi, G. Rice cultivation in Italy under the threat of climatic change: Trends, technologies and research gaps. Irrig. Drain. 2020, 69, 517-530. [CrossRef]

8. Redona, E.D.; Mackill, D.J. Quantitative trait locus analysis for rice panicle and grain characteristics. Theor. Appl. Genet. 1998, 96, 957-963. [CrossRef]

9. Tesio, F.; Tabacchi, M.; Cerioli, S.; Follis, F. Sustainable hybrid rice cultivation in Italy. A review. Agron. Sustain. Dev. 2014, 34, 93-102. [CrossRef]

10. Marques-Avila, A. El consumo de arroz crece en España y en el mundo. Distrib. Consumo 2021, 1, 113-116.

11. Palmerín, J.A.; Junta de Extremadura, Don Benito, Badajoz, Spain. Personal communication, 2021.

12. Zeng, F.; Ali, S.; Zhang, H.; Ouyang, Y.; Qiu, B.; Wu, F.; Zhang, G. The influence of pH and organic matter content in paddy soil on heavy metal availability and their uptake by rice plants. Environ. Pollut. 2011, 159, 84-91. [CrossRef] [PubMed]

13. Auffhammer, M.; Ramanathan, V.; Vincent, J.R. Climate change, monsoon, and rice yield in India. Clim. Chang. 2011, 111, 411-422. [CrossRef]

14. Shimono, H.; Hasegawa, T.; Fujimura, S.; Iwama, K. Responses of leaf photosynthesis and plant water status in rice to low water temperature at different growth stages. Field Crops Res. 2004, 89, 71-83. [CrossRef]

15. Ferrero, A.; Tinarelli, A. Rice Cultivation in the E.U. Ecological Conditions and Agronomical Practices: 1-24. In Pesticide Risk Assessment in Rice Paddies: Theory and Practice; Elsevier: Amsterdam, The Netherlands, 2008.

16. Kraehmer, H.; Jabran, K.; Mennan, H.; Chauhan, B.S. Global distribution of rice weeds-A review. Crop Prot. 2016, 80, 73-86. [CrossRef]

17. Kraehmer, H.; Thomas, C.; Vidotto, F. Rice production in Europe. In Rice Production Worldwide; Springer International Publishing: Cham, Switzerland, 2017.

18. Kaloumenos, N.S.; Chatzilazaridou, S.L.; Mylona, P.V.; Polidoros, A.N.; Eleftherohorinos, I.G. Target-site mutation associated with cross-resistance to ALS-inhibiting herbicides in late watergrass (Echinochloa oryzicola Vasing.). Pest Manag. Sci. 2013, 69, 865-873. [CrossRef] [PubMed]

19. Scarabel, L.; Farinati, S.; Sattin, M. Occurrence of Resistance to ALS Inhibitors in European Cyperus esculentus L.: Characterisation and Implications for Management. Agronomy 2020, 10, 1133. [CrossRef]

20. Norsworthy, J.K.; Bond, J.; Scott, R.C. Weed management practices and needs in Arkansas and Mississippi rice. Weed Technol. 2013, 27, 623-630. [CrossRef]

21. Osuna, M.D.; Vidotto, F.; Fischer, A.J.; Bayer, D.E.; De Prado, R.; Ferrero, A. Cross-resistance to bispyribac-sodium and bensulfuron-methyl in Echinochloa phyllopogon and Cyperus difformis. Pestic. Biochem. Physiol. 2002, 73, 9-17. [CrossRef]

22. Iwakami, S.; Hashimoto, M.; Matsushima, K.; Watanabe, H.; Hamamura, K.; Uchino, A. Multiple-herbicide resistance in Echinochloa crus-galli var. formosensis, an allohexaploid weed species, in dry-seeded rice. Pestic. Biochem. Physiol. 2015, 119, 1-8. [CrossRef]

23. Wang, X.L.; Zhang, Z.Y.; Xu, X.M.; Li, G. The density of barnyard grass affects photosynthesis and physiological characteristics of rice. Photosynthetica 2019, 57, 705-711. [CrossRef]

24. Olofsdotter, M.; Valverde, B.E.; Madsen, K.H. Herbicide resistant rice (Oryza sativa L.): Global implications for weedy rice and weed management. Ann. Appl. Biol. 2000, 137, 279-295. [CrossRef]

25. López, G. Orientaciones Generales Para el Empleo de Herbicidas en el Cultivo del Arrozal y la Siembra Directa del Arrozal; Publicaciones del Departamento de Información, Prensa y Propaganda, 1965; p. 31. 
26. Ministerio de Agricultura, Pesca y Alimentación. Pesticide Database. Available online: https://www.mapa.gob.es/es/ agricultura/temas/sanidad-vegetal/productos-fitosanitarios/registro/menu.asp (accessed on 1 May 2021).

27. Osuna, M.D.; Romano, Y.; Gordo, R.; Cabanillas, T.; De Santiago, A.; Palmerin, J.A.; Quiles, J.M. Problemática de malas hierbas en el cultivo de arroz en Extremadura. Agricultura 2020, 1036, 60-64.

28. Pardo, G.; Marí, A.; Fernández-Cavada, S.; García-Floria, C.; Hernández, S.; Zaragoza, C.; Cirujeda, A. Alternatives to Penoxsulam to Control Echinochloa Spp. And Cyperaceous Weeds in Rice Crop in NE Spain. ITEA Inf. Tec. Econ. Agrar. 2015, 111, $295-309$.

29. Amaro-Blanco, I.; Romano, Y.; Palmerin, J.A.; Gordo, R.; Palma-Bautista, C.; De Prado, R.; Osuna, M.D. Different Mutations Providing Target Site Resistance to ALS- and ACCase-Inhibiting Herbicides in Echinochloa spp. from Rice Fields. Agriculture 2021, 11, 382. [CrossRef]

30. Heap, I. International Survey of Herbicide Resistant Weeds. Available online: http://www.weedscience.org/Summary/Species. aspx (accessed on 1 May 2021).

31. Jugulam, M.; Shyam, C. Non-Target-Site Resistance to Herbicides: Recent Developments. Plants 2019, 15, 417. [CrossRef] [PubMed]

32. Powles, S.; Yu, Q. Evolution in Action: Plants Resistant to Herbicides. Annu. Rev. Plant Biol. 2010, 61, 317-347. [CrossRef]

33. Amaro, I. Resistencia de Malas Hierbas a Herbicidas en el Cultivo del Arroz y en Cultivos Leñosos: Estudios de Mecanismos de Resistencia. Tesis Doctoral, Universidad de Extremadura, 2019. Available online: http://dehesa.unex.es/handle/10662/9998 (accessed on 1 May 2021).

34. Tranel, P.J.; Wright, T.R.; Heap, I.M. Mutations in Herbicide-Resistant Weeds to ALS Inhibitors. 2021. Available online: http:/ / www.weedscience.com (accessed on 1 May 2021).

35. Liu, J.; Fang, J.; He, Z.; Li, J.; Dong, L. Target site-based resistance to penoxsulam in late watergrass (Echinochloa phyllopogon) from China. Weed Sci. 2019, 67, 380-388. [CrossRef]

36. Matzenbacher, F.O.; Bortoly, E.D.; Kalsing, A.; Merotto, A. Distribution and analysis of the mechanisms of resistance of barnyardgrass (Echinochloa crus-galli) to imidazolinone and quinclorac herbicides. J. Agric. Sci. 2015, 153, 1044-1058. [CrossRef]

37. Panozzo, S.; Scarabel, L.; Tranel, P.J.; Sattin, M. Target-site resistance to ALS inhibitors in the polyploid species Echinochloa crus-galli. Pestic. Biochem. Physiol. 2013, 105, 93-101. [CrossRef]

38. Deng, W.; Cai, J.; Zhang, J.; Chen, Y.; Di, Y.; Yuan, S. Molecular basis of resistance to ACCase-inhibiting herbicide cyhalofop-butyl in Chinese sprangletop (Leptochloa chinensis (L.) Nees) from China. Pestic. Biochem. Physiol. 2019, 158, 143-148. [CrossRef] [PubMed]

39. Li, Z.; Li, X.; Chen, J.; Peng, L.; Wang, J.; Cui, H. Variation in mutations providing resistance to acetohydroxyacid synthase inhibitors in Cyperus difformis in China. Pestic. Biochem. Physiol. 2020, 166, 104571. [CrossRef] [PubMed]

40. Martin, R.; Chhun, S.; Yous, S.; Rien, R.; Korn, C.; Srean, P. Survey of Weed Management Practices in Direct-Seeded Rice in North-West Cambodia. Agronomy 2021, 11, 498. [CrossRef]

41. Osuna, M.D.; Centro de Investigaciones Científicas y Tecnológicas de Extremadura, Guadajira, Badajoz, Spain. Personal communication, 2021.

42. Talbert, R.E.; Burgos, N.R. History and Management of Herbicide-resistant Barnyardgrass (Echinochloa crus-galli) in Arkansas Rice. Weed Technol. 2007, 21, 324-331. [CrossRef]

43. Rodenburg, J.; Meinke, H.; Johnson, D.E. Challenges for weed management in African rice systems in a changing climate. J. Agric. Sci. 2011, 149, 427-435. [CrossRef]

44. Refatti, J.P.; de Avila, L.A.; Camargo, E.R.; Ziska, L.H.; Oliveira, C.; Salas-Perez, R.; Rouse, C.E.; Roma-Burgos, N. High [CO 2 ] and Temperature Increase Resistance to Cyhalofop-Butyl in Multiple-Resistant Echinochloa colona. Front. Plant. Sci. 2019, 10, 529. [CrossRef]

45. Young, M.L.; Norsworthy, J.K.; Scott, R.C.; Bond, J.A.; Heiser, J. Benzobicyclon as a Post-Flood Option for Weedy Rice Control. Weed Technol. 2018, 32, 371-378. [CrossRef]

46. Peng, Y.; Cheng, X.; Liu, D.; Ma, G.; Li, S.; Yang, Y.; Zhang, Y.; Bai, L. Quintrione: A new selective herbicide for weed control in rice (Oryza sativa L.). Crop Prot. 2021, 141, 105501. [CrossRef]

47. Zabala, D.; Carranza, N.; Darghan, A.; Plaza, G. Spatial distribution of multiple herbicide resistance in Echinochloa colona (L.) Link. Chil. J. Agric. Res. 2019, 79, 576-585. [CrossRef]

48. Iqbal, N. Effective Weed Management in Dry Direct Seeded Rice for Sustainable Productivity. Appl. Sci. Bus. Econ. 2017, 4, 1-8.

49. Juliano, L.M.; Casimero, M.C.; Llewellyn, R. Multiple herbicide resistance in barnyardgrass (Echinochloa crus-galli) in direct-seeded rice in the Philippines. Int. J. Pest Manag. 2010, 56, 299-307. [CrossRef]

50. Chen, G.; Wang, Q.; Yao, Z.; Zhu, L.; Dong, L. Penoxulam-resistant barnyardgrass (Echinochloa crus-galli) in rice fields in China. Weed Biol. Manag. 2016, 16, 16-23. [CrossRef]

51. Fisher, A.J.; Ateh, C.M.; Bayer, D.E.; Hill, J.E. Herbicide-resistant Echinochloa oryzoides and E. phyllopogon in California Oryza sativa fields. Weed Sci. 2000, 48, 225-230. [CrossRef]

52. Kacan, K.; Tursun, N.; Ullah, H.; Datta, A. Barnyardgrass (Echinochloa crus-galli (L.) P. Beauv.) resistance to acetolactate synthaseinhibiting and other herbicides in rice in Turkey. Plant Soil Environ. 2020, 66, 357-365. [CrossRef] 